\title{
Intestinal Parasites among Patients attending General Central Public Health Laboratory in Erbil City-Iraq during 1998-2004
}

\section{Narmin Rafiq Hamad}

Department of Biology / College of Science

University of Salahaddin / Erbil, Iraq

Received

08 / 03 / 2009
Accepted

14 / 09 / 2010

\section{الخلاصة}

تم جمع البيانات الخاصة بنماذج البراز للمرضى الوافدين الى مختبر الصحة العامة المركزي في مدينة أربيل خلا السنوات 1998 - 2004، لتقدير و تعيين النسب المئوية

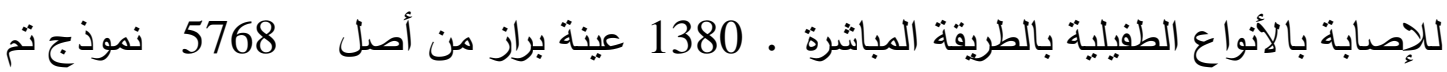
فحصها، كانت مصابة بالطفيليات المعوية 23.9\% . من خلال التحليل الإحصائي للنتائج، وجدت فروق معنوية عالية بين الإصابات من جهة وكل من سنوات الدراسة و توزيع الأنواع الطفيلية نسبة الى جنس المرضى من جهة أخرى .

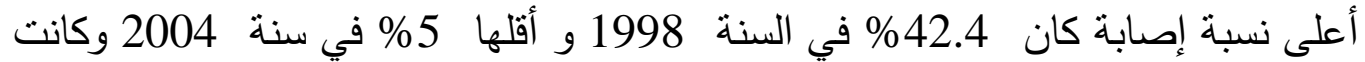
إصابة الذكور أعلى منها في الإناث 60.2\% و 39.8\% على النوالي.

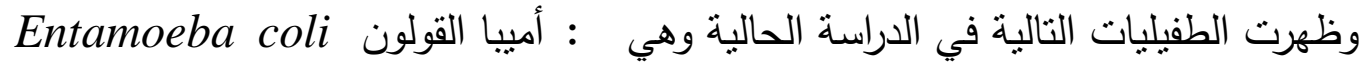

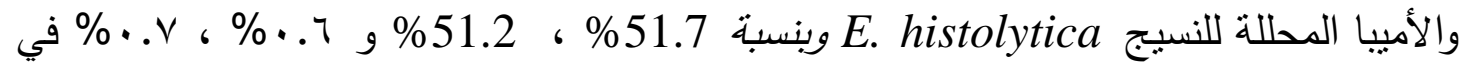
الذكور والأناث على التوالي، و جيارديا لامبليا Giardia lamblia و الشعرة المعوية hominis Trichomonas الذكور والأناث على التوالي ، و دودة البقر الثريطية Taenia saginata

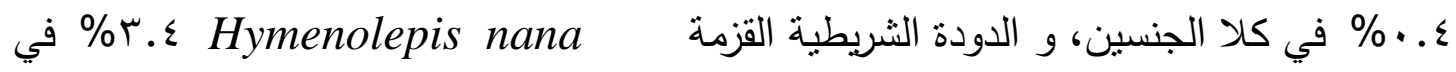

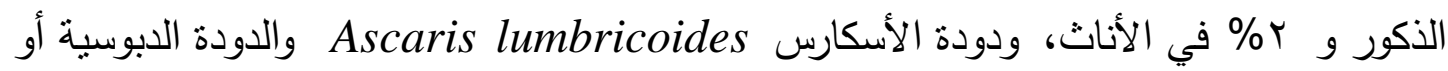

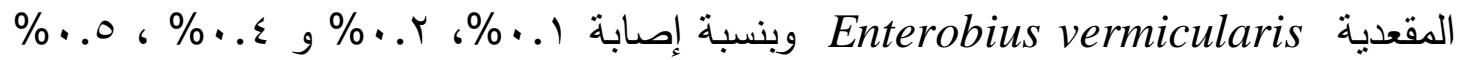
في الذكور والأناث على النوالي. 


$$
\begin{aligned}
& \text { تم تسجيل فقط } 57 \text { حالة دن الإصابة المزدوجة بالطفيليات ـ وجدت نسبة عالية من } \\
& \text { خلايا القيح وكريات الدم الحمراء وفطريات المونيليا في عينات البراز للمصابين بالطفيليات }
\end{aligned}
$$

A. ، H. nana ، T. saginata ، G. lamblia ، E. histolytica المعوية الممرضة منت

. E. vermicularis g lumbricoides

Keywords: Intestinal Parasites, Erbil.

\begin{abstract}
The data of general stool examination of the patients attending the general central public health laboratory in Erbil city were collected during years 1998-2004 to estimate and determine the percentage of infections with parasitic species by direct method. Out of 5768 stool samples, examined 1380 were infected with intestinal parasites $23.9 \%$. Statistically, there were high significant differences between infections and each of studied years and distribution of the parasitic species in relation to the sexes of the patients. Highest infection rate was $42.4 \%$ in the year 1998, while the lowest was $5 \%$ in 2004 , and the males were infected with intestinal parasites more than females which were $60.2 \%$ and $39.8 \%$ respectively.

The following parasites were detected in the present study: Entamoeba histolytica and Entamoeba coli with infection rates $51.7 \%$, $51.2 \%$ and $0.6 \%, 0.7 \%$ in males and females, respectively, and intestinal flagellates, Giardia lamblia and Trichomonas hominis 40.3\%, 39.9\% and $3.1 \%, 5.1 \%$ in males and females, respectively. Taenia saginata $0.4 \%$ in each of males and females and Hymenolepis nana $3.4 \%$ in males and $2 \%$ in females, Ascaris lumbricoides and Enterobius vermicularis $0.1 \%$, $0.2 \%$, and $0.4 \%, 0.5 \%$ in males and females, respectively. Only 57 cases with double infections were recorded.

High percentages of pus cells, red blood cells and Monilia fungi were present in the infected stools with pathogenic intestinal parasites like E. histolytica, G. lamblia, T. saginata, H. nana, A. lumbricoides and E. vermicularis.
\end{abstract}

\title{
Introduction
}

Protozoan infections of the intestine cause a wide variety of clinical symptoms, ranging from asymptomatic carrier to severe disease associated with pathologic lesions in the gastrointestinal tract or other organs [1]. Parasitic helminthes are one of the major public health problems; they may not directly produce serious disease in the human but may indirectly rob the individual's energy, interfere with his nutrition and make him more susceptible to other diseases [2]. 
There are inadequate informations on the parasitic infestations of man in developing countries. Information from in-patient and out-patient sections of hospitals is most useful for the planning of meaningful public health programs, and surveys based on hospital records in Erbil city include those of [3], who studied the intestinal parasites among pediatric hospital patients and out-patients that had diarrhea, in a study performed by [4] among 33803 examined stool samples, 7566 (22.4\%) were infected, the prevalence of intestinal parasites were studied by [5] and a total of 1366 stool specimens of children aged from 4 months to 6 years were examined and of these, 837(61.27\%) were positive for E. histolytica and G. lamblia. In a retrospective study recorded by [6], 4544 cases were positive $(26.9 \%)$ for the presence of G. lamblia out of 16900 stool samples which were collected from patients of Endemic Disease Center [7] performed a study on the causative agents of diarrhea in regular patients of Maternity and Pediatric Hospital and found that $66.5 \%$ of cases were caused by different kinds of parasites.

In another studies which were carried out in Erbil city, 34 cases (29.6\%) were found to be infected with one or more intestinal parasites among 115 examined stool specimens in some of the kindergartens [8], and the infection rate of the intestinal parasites was $50.4 \%$ among patients in Maternity and Pediatric Hospital [9], while a prospective study was conducted by [10] and revealed that the total rates of infection with intestinal parasites among foodhandlers and rural primary schoolchildren were $26.58 \%$ and $40.15 \%$ respectively, and [11] recorded a high rate of infection $32.29 \%$ among primary schoolchildren and the higher rate was detected among those in rural areas $33.42 \%$ in compare to urban $29.6 \%$.

Several researchers studied the intestinal parasites in different regions in Iraq such as [12] in Ninevah governorate and [13] in AlTaam'em province and they recorded the total percentages of infection among primary schoolchildren and foodhandlers $50.6 \%, 29.4 \%$ and $41.61 \%, 26.77 \%$ respectively. While [14] found that $44.53 \%$ was the infection rate of intestinal parasites among pupils of a number of primary schools and kindergarten children in the right side of Mosul city.

The prevalence of gastrointestinal parasites among population in Dohuk-Kurdistan region of Iraq was studied by [15] and they reported that the percentage of infection was (57.9\%) out of 380 stool samples collected from patients attending the outpatient clinic of Azady Hospital and the private laboratories.

\section{Materials and Methods}

The data and information of general stool examination of 5768 patients attending to the general central public health laboratory in Erbil city during 1998-2004, were included in this study. The collected specimens were examined by using direct method for the parasites detection. General stool examination has performed using wet mount 
technique, and then the results were analyzed statistically by using $X^{2}$ chi-square value according to [16].

\section{Results and Discussion}

Out of 5768 examined stool specimens, 1380 were positive for intestinal parasites, the infection rate was $23.9 \%$ - Table (1).

The result of the present study is much lower than the finding of [15] in Duhok $57.9 \%$ and slightly higher than that recorded by each of [3] $21.6 \%$ and [4] $22.4 \%$ in Erbil city.

The high parasitic prevalence in the current study may resulted from different factors such as lower standards of sanitation, the greater longevity of the infective stage of the parasite in a favorable environment, low level of personal hygiene and socioeconomic status and the immunity degree of the studied groups, inadequate drinking water supply [17], and also presence of asymptomatic carriers which are considered the main source of infection due to the excretion of the infective stages in their stools [15].

Table (1) also shows high significant differences were present among the infections during the studied years, the highest infection rate 42.4\% was in the year 1998 which may be because the year (1998-1999) was characterized by drought and frequent dust in addition to the reduction in the rainfall rate in the region [13], and lowest rate 5\% was in 2004 which is explained by the improvement in the level of environmental sanitation, socioeconomic status of the population, the water supply of the city, detection and evaluation of clinical importance of the disease in the patients and support and cooperation in community preventive measures which reduce the prevalence of various intestinal parasites.

Table (1): Distribution of intestinal parasites among patients attending General Central Public Health Laboratory in Erbil city during years 1998-2004.

\begin{tabular}{|c|c|c|c|}
\hline Year & $\begin{array}{c}\text { No. } \\
\text { examined }\end{array}$ & No. +ve & \% \\
\hline 1998 & 1112 & 472 & 42.4 \\
\hline 1999 & 1090 & 341 & 31.3 \\
\hline 2000 & 462 & 125 & 27.1 \\
\hline 2001 & 1232 & 236 & 19.2 \\
\hline 2002 & 427 & 108 & 25.3 \\
\hline 2003 & 197 & 35 & 17.8 \\
\hline 2004 & 1248 & 63 & 5 \\
\hline Total & $\mathbf{5 7 6 8}$ & $\mathbf{1 3 8 0}$ & $\mathbf{2 3 . 9}$ \\
\hline
\end{tabular}

Calculated $X^{2}=508.42, \quad$ Tabulated $X^{2}=16.8, \quad(p<0.01)$. 
Table (2), revealed distribution of intestinal parasites according to the patient's sex; males were highly infected than females $(60.2 \%$ and $39.8 \%$ ) respectively, which indicate that females have hygienic habit and take care of their personal cleanlines more than males. The high rate of infection with intestinal parasites among males in this study is in agreement with other studies conducted in Iraq [8], [4], and [15].

Two of each of intestinal amebae and flagellates were investigated in the present study, which were (E. coli and E. histolytica, G. lamblia and $T$. hominis), and two of each of cestodes and nematodes (T. saginata, and $H$. nana, A. lumbricoides and E. vermicularis).

Among the recorded parasites, E. coli and T. hominis are nonpathogenic parasites (commensals). There were 57 double infections in the current study, as indicated in Table (3), infection with more than one parasite may be mainly due to the exposure to multiple parasite infections or the response of the patient to the infection with one parasite may give an opportunity for another parasite to be established in the same host and at the same time [13].

G. lamblia $42(73.7 \%)$ and E. histolytica $14(24.6 \%)$ were the most frequent and predominant recorded parasites, and this widespread infection is a reflection of the sanitation level and water treatment, in addition, they have direct life cycles and transmission occurs by contaminated food and water by infected sewage, filth flies act as important mechanical vectors of the cysts or through the carriers (cyst passers) handling food that can infect others [17].

The high percentages of the pathological intestinal parasites explained strongly with the presence of the pus cells, red blood cells and Monilia (fungi) in the feces with pathogenic parasites- Table (4). In this study, E. histolytica, G. lamblia, T. saginata, H. nana, A. lumbricoides and $E$. vermicularis were the detected pathogenic parasites, and infection with A. lumbricoides revealed $100 \%$ of each of pus cells, RBCs and Monilia.

Many factors play important roles to determine the effects of the intestinal parasites such as the strain, number, size and the site of the parasite, in addition to the metabolic processes of the parasite particularly the nature of any waste products [17] and [11]. 
Table (2): Distribution of intestinal parasitic species in relation to the sex of the patients attending General Central Public Health Laboratory in Erbil city during years 1998-2004.

\begin{tabular}{|c|c|c|c|c|c|c|c|c|c|c|c|c|c|c|c|c|c|}
\hline \multirow{2}{*}{ Parasite } & \multirow{2}{*}{ Sex } & \multicolumn{2}{|c|}{1998} & \multicolumn{2}{|c|}{1999} & \multicolumn{2}{|c|}{2000} & \multicolumn{2}{|c|}{2001} & \multicolumn{2}{|c|}{2002} & \multicolumn{2}{|c|}{2003} & \multicolumn{2}{|c|}{2004} & \multicolumn{2}{|c|}{ Total } \\
\hline & & No. & $\%$ & No. & $\%$ & No. & $\%$ & No. & $\%$ & No. & $\%$ & No. & $\%$ & No. & $\%$ & No. & $\%$ \\
\hline $\begin{array}{l}\text { Protozoa } \\
\text { Entamoeba coli }\end{array}$ & $\begin{array}{l}\hat{1} \\
0 \\
+\end{array}$ & $\begin{array}{l}1 \\
1\end{array}$ & $\begin{array}{l}0.3 \\
0.6\end{array}$ & $\begin{array}{l}3 \\
1\end{array}$ & $\begin{array}{l}1.6 \\
0.7\end{array}$ & - & - & $\overline{1}$ & $\overline{1}$ & $\begin{array}{l}1 \\
1\end{array}$ & $\begin{array}{l}1.5 \\
2.5\end{array}$ & - & $\begin{array}{l}- \\
-\end{array}$ & - & - & $\begin{array}{l}5 \\
4\end{array}$ & $\begin{array}{l}0.6 \\
0.7\end{array}$ \\
\hline E. histolytica & $\begin{array}{l}1 \\
0 \\
0\end{array}$ & $\begin{array}{c}174 \\
90\end{array}$ & $\begin{array}{l}57.8 \\
52.6\end{array}$ & $\begin{array}{c}104 \\
82\end{array}$ & $\begin{array}{l}54.7 \\
54.3\end{array}$ & $\begin{array}{l}36 \\
25\end{array}$ & $\begin{array}{l}46.8 \\
52.1\end{array}$ & $\begin{array}{l}55 \\
46\end{array}$ & $\begin{array}{c}42 \\
43.8\end{array}$ & $\begin{array}{l}30 \\
19\end{array}$ & $\begin{array}{l}44.1 \\
47.5\end{array}$ & $\begin{array}{l}8 \\
9\end{array}$ & $\begin{array}{c}44.4 \\
53\end{array}$ & $\begin{array}{l}23 \\
10\end{array}$ & $\begin{array}{c}50 \\
58.8\end{array}$ & $\begin{array}{l}430 \\
281\end{array}$ & $\begin{array}{l}51.7 \\
51.2\end{array}$ \\
\hline Giardia lamblia & $\begin{array}{l}1 \\
0 \\
0\end{array}$ & $\begin{array}{c}112 \\
72\end{array}$ & $\begin{array}{l}37.2 \\
42.1\end{array}$ & $\begin{array}{l}75 \\
62\end{array}$ & $\begin{array}{l}39.5 \\
41.1\end{array}$ & $\begin{array}{l}33 \\
17\end{array}$ & $\begin{array}{l}42.9 \\
35.4\end{array}$ & $\begin{array}{l}57 \\
39\end{array}$ & $\begin{array}{l}43.5 \\
37.1\end{array}$ & $\begin{array}{l}28 \\
15\end{array}$ & $\begin{array}{l}41.2 \\
37.5\end{array}$ & $\begin{array}{l}9 \\
7\end{array}$ & $\begin{array}{c}50 \\
41.2\end{array}$ & $\begin{array}{c}21 \\
7\end{array}$ & $\begin{array}{l}45.7 \\
41.2\end{array}$ & $\begin{array}{l}335 \\
219\end{array}$ & $\begin{array}{l}40.3 \\
39.9\end{array}$ \\
\hline Trichomonas hominis & $\begin{array}{l}0 \\
0\end{array}$ & $\begin{array}{l}2 \\
3\end{array}$ & $\begin{array}{l}0.7 \\
1.8\end{array}$ & $\begin{array}{l}2 \\
4\end{array}$ & $\begin{array}{l}1.1 \\
2.6\end{array}$ & $\begin{array}{l}3 \\
6\end{array}$ & $\begin{array}{c}3.9 \\
12.5\end{array}$ & $\begin{array}{l}14 \\
13\end{array}$ & $\begin{array}{l}10.7 \\
12.4\end{array}$ & $\begin{array}{l}4 \\
2\end{array}$ & $\begin{array}{c}5.9 \\
5\end{array}$ & $\begin{array}{l}- \\
-\end{array}$ & $\begin{array}{l}- \\
-\end{array}$ & $\begin{array}{l}1 \\
-\end{array}$ & 2.2 & $\begin{array}{l}26 \\
28\end{array}$ & $\begin{array}{l}3.1 \\
5.1\end{array}$ \\
\hline $\begin{array}{c}\text { Helminths } \\
\text { A- Cestoda } \\
\text { Taenia saginata }\end{array}$ & $\begin{array}{l}\hat{0} \\
0 \\
+\end{array}$ & $\begin{array}{l}1 \\
1\end{array}$ & $\begin{array}{l}0.3 \\
0.6\end{array}$ & $\begin{array}{l}- \\
-\end{array}$ & - & $\begin{array}{l}1 \\
-\end{array}$ & $\begin{array}{c}1.3 \\
-\end{array}$ & $\begin{array}{l}1 \\
1\end{array}$ & $\begin{array}{c}0.8 \\
1\end{array}$ & - & - & - & - & - & - & $\begin{array}{l}3 \\
2\end{array}$ & $\begin{array}{l}0.4 \\
0.4\end{array}$ \\
\hline Hymenolepis nana & $\begin{array}{l}1 \\
0 \\
0\end{array}$ & $\begin{array}{l}8 \\
2\end{array}$ & $\begin{array}{l}1.7 \\
1.2\end{array}$ & $\begin{array}{l}5 \\
2\end{array}$ & $\begin{array}{l}2.6 \\
1.3\end{array}$ & $\begin{array}{l}4 \\
-\end{array}$ & $\begin{array}{c}5.2 \\
-\end{array}$ & $\begin{array}{l}4 \\
3\end{array}$ & $\begin{array}{l}3.1 \\
2.9\end{array}$ & $\begin{array}{l}5 \\
3\end{array}$ & $\begin{array}{l}7.4 \\
7.5\end{array}$ & $\begin{array}{l}1 \\
1\end{array}$ & $\begin{array}{l}5.6 \\
5.9\end{array}$ & $\begin{array}{l}1 \\
-\end{array}$ & $\begin{array}{c}2.2 \\
-\end{array}$ & $\begin{array}{l}28 \\
11\end{array}$ & $\begin{array}{c}3.4 \\
2\end{array}$ \\
\hline $\begin{array}{l}\text { B- Nematoda } \\
\text { Ascaris lumbricoides }\end{array}$ & $\begin{array}{l}\pi \\
0 \\
0\end{array}$ & $\begin{array}{l}1 \\
1\end{array}$ & $\begin{array}{l}0.3 \\
0.6\end{array}$ & - & - & - & - & - & - & - & $\begin{array}{l}- \\
-\end{array}$ & - & $\begin{array}{l}- \\
-\end{array}$ & $\begin{array}{l}- \\
-\end{array}$ & $\begin{array}{l}- \\
-\end{array}$ & $\begin{array}{l}1 \\
1\end{array}$ & $\begin{array}{l}0.1 \\
0.2\end{array}$ \\
\hline Enterobius vemicularis & $\begin{array}{l}\hat{0} \\
0 \\
0\end{array}$ & $\begin{array}{l}2 \\
1\end{array}$ & $\begin{array}{l}0.7 \\
0.6\end{array}$ & $\begin{array}{l}1 \\
-\end{array}$ & $\begin{array}{c}0.5 \\
-\end{array}$ & - & - & $\overline{2}$ & $\overline{1.9}$ & - & - & - & - & $\begin{array}{l}- \\
-\end{array}$ & - & $\begin{array}{l}3 \\
3\end{array}$ & $\begin{array}{l}0.4 \\
0.5\end{array}$ \\
\hline Total & $\begin{array}{l}\hat{1} \\
0 \\
+\end{array}$ & $\begin{array}{l}301 \\
171\end{array}$ & $\begin{array}{l}63.8 \\
36.2\end{array}$ & $\begin{array}{l}190 \\
151\end{array}$ & $\begin{array}{l}55.7 \\
44.3\end{array}$ & $\begin{array}{l}77 \\
48\end{array}$ & $\begin{array}{l}61.6 \\
38.4\end{array}$ & $\begin{array}{l}131 \\
105\end{array}$ & $\begin{array}{l}55.5 \\
44.5\end{array}$ & $\begin{array}{l}68 \\
40\end{array}$ & $\begin{array}{l}63 \\
37\end{array}$ & $\begin{array}{l}18 \\
17\end{array}$ & $\begin{array}{l}51.4 \\
48.6\end{array}$ & $\begin{array}{l}46 \\
17\end{array}$ & $\begin{array}{l}73 \\
27\end{array}$ & $\begin{array}{l}831 \\
549\end{array}$ & $\begin{array}{l}60.2 \\
39.8\end{array}$ \\
\hline Total Sum $(\hat{0}+\phi)$ & & 472 & & 341 & & 125 & & 236 & & 108 & & 35 & & 63 & & 1380 & \\
\hline
\end{tabular}

Calculate $X^{2}=57.61$, Tabulated $X^{2}=6.6, \quad(P<0.01)$. 
Table (3): Double infections among patients attending General Central Public Health Laboratory in Erbil city during years 1998-2004.

\begin{tabular}{|c|c|c|c|c|}
\hline Parasite & G. lamblia & E. histolytica & T. saginata & Total \\
\hline E. coli & 1 & 3 & - & $\mathbf{4}$ \\
\hline E. histolytica & 33 & - & - & $\mathbf{3 3}$ \\
\hline T. hominis & 5 & 9 & - & $\mathbf{1 4}$ \\
\hline H. nana & 3 & 2 & 1 & $\mathbf{6}$ \\
\hline Total & $\mathbf{4 2}$ & $\mathbf{1 4}$ & $\mathbf{1}$ & $\mathbf{5 7}$ \\
\hline
\end{tabular}

Table (4): Findings of general stool examination for pathogenic intestinal parasites among patients attending General Central Public Health Laboratory in Erbil city during years 1998-2004.

\begin{tabular}{|l|c|c|c|c|c|c|c|}
\hline \multirow{2}{*}{\multicolumn{1}{|c|}{ Parasite }} & \multicolumn{7}{|c|}{ Total } \\
\cline { 2 - 8 } & $\begin{array}{c}\text { No. +ve } \\
\text { cases }\end{array}$ & Pus cells & $\%$ & R.B.Cs & $\%$ & Monilia & $\%$ \\
\hline E. histolytica & 711 & 708 & 99.6 & 709 & 99.7 & 442 & 62.2 \\
\hline G. lamblia & 554 & 507 & 91.5 & 466 & 84.1 & 451 & 81.4 \\
\hline T. saginata & 5 & 4 & 80 & 3 & 60 & 1 & 20 \\
\hline H. nana & 39 & 29 & 74.4 & 29 & 74.4 & 13 & 33.3 \\
\hline A. lumbricoides & 2 & 2 & 100 & 2 & 100 & 2 & 100 \\
\hline E. vermicularis & 6 & 3 & 50 & 2 & 33.3 & 2 & 33.3 \\
\hline
\end{tabular}

\section{References:}

(1) Behrman, R. E., Kliegman R. M., Nelson, W. E. and Vaughan V. (1992). Behrman text book of pediatrics, $14^{\text {th }}$ edition. W.B. Saunders Company.

(2) World Health Organization (1964). Soil-transmitted helminthes. port of a WHO Expert Committee. WHO Tech. Rep. Ser. No. 277.

(3) Kadir, M.A., Kader A.A., and Faraj K.K. (1987). Survey study of the intestinal parasites among different populations of Erbil city. J. Fac. Med. Baghdad, 29 (4): 455-458.

(4) Salih, I. J. (1991). Parasitic infestation in Erbil. Zanko J. Univ. of Salahaddin, 4 (3): 93-102.

(5) Hussein, M.M.S. (1997). Prevalence of intestinal parasites in children up to 6 years old in Erbil province, Iraq. Zanko J. Univ. of Salahaddin, special issue 1:59-64. 
(6) Salih, I.J. (1998). Epidemiology of Giardiasis in Erbil. Zanko J. Univ. of Salahaddin, 10 (2): 15-18.

(7) Abdullah, S.M., Darogha, S.N., and Shakhainy, K.A. (1999). A study on the causative agents of diarrhea in regular patients of Maternity and Pediatric hospital in Erbil. JDU (Sci), Special Issue, 2 (3): 397-406.

(8) Faraj, A.M. (2000). Prevalence of intestinal parasites in some of kindergartens in the center of Erbil-Northern Iraq. JDU., 3 (1): 7 12.

(9) Hawezy, A.A. (2004). Prevalence of parasitic infection among patients of maternity and pediatric hospital in Erbil-KurdistanIraq. Zanko J. Univ. of Salahaddin, 16 (3): 25-29.

(10) Ahmed, Q.M. (2006). Prevalence of intestinal parasites among foodhandlers and primary schoolchildren in Erbil province, with initial cultivation of Entamoeba histolytica Schaudinn, 1903. M.Sc. Thesis, College of Education, University of Salahaddin.

(11) Hama, A.A. (2007). Intestinal parasites in relation to malnutrition among primary schoolchildren in Erbil province, with evaluation of some anti-parasitic drugs. M.Sc. Thesis, College of Science, University of Salahaddin.

(12) Al-Daoody, A.A.K. (1998). Epidemiology of intestinal parasites among pupils of anumber of primary schools and foodhandlers in Ninevah governorate. M.Sc. Thesis, College of Science, University of Mosul.

(13) Al-Shirifi, H.M.H. (2000). Prevalence of intestinal parasites among pupils of primary schools and foodhandlers in Al-Taam'em province-Iraq. M.Sc. Thesis, College of Education, University of Mosul.

(14) Al-Abbadie, A.I.A.M. (2001). Epidemiology of intestinal parasites among pupils of a number of primary schools and kindergarten children in Mosul city and attempt to infect laboratory mice with Enterobius vermicularis. M.Sc. Thesis, College of Education, University of Mosul.

(15) Al-Saeed, A.I., Saeed, A.Y. and Mohammed, J.B. (2001). Prevalence of gastrointestinal parasites among population in Dohuk-Kurdistan Region-Iraq. Zanko J. Medical, Sci., 5, Special Issue: 14-18.

$$
\begin{aligned}
& \text { الراوي، خاشع محمود و عبدالعزيز محمد خلف اله (9191)). تصميم وتحليل }
\end{aligned}
$$

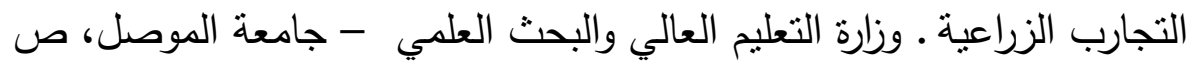

$$
\begin{aligned}
& \text {. rT }
\end{aligned}
$$

(17) Roberts, L.S. and Janovy, J. (2005). Foundations of parasitology. $7^{\text {th }}$ Edition. McGraw Hill Companies. 